\title{
HCV-RNA quantification in liver bioptic samples and extrahepatic compartments, using the abbott RealTime HCV assay
}

\author{
FrancescoPaolo Antonucci $^{\mathrm{a}}$, Valeria Cento ${ }^{\mathrm{a}}$, Maria Chiara Sorbo ${ }^{\mathrm{a}}$, Matteo Ciancio Manuelli ${ }^{\mathrm{b}}$, \\ Ilaria Lenci ${ }^{\mathrm{c}}$, Daniele Sforza ${ }^{\mathrm{b}}$, Domenico Di Carlo ${ }^{\mathrm{a}}$, Martina Milana ${ }^{\mathrm{c}}$, Tommaso Maria Manzia ${ }^{\mathrm{b}}$, \\ Mario Angelico $^{c}$, Giuseppe Tisone ${ }^{\mathrm{b}}$, Carlo Federico Perno ${ }^{\mathrm{a}}$, Francesca Ceccherini-Silberstein ${ }^{\mathrm{a}, *}$ \\ a Department of Experimental Medicine and Surgery, University of Rome Tor Vergata, Rome, Italy \\ b Liver Unit, Polyclinic Tor Vergata Foundation, University of Rome Tor Vergata, Rome, Italy \\ ${ }^{\mathrm{c}}$ Hepatology Unit, Polyclinic Tor Vergata Foundation, University of Rome Tor Vergata, Rome, Italy
}

\section{A R T I C L E I N F O}

\section{Keywords:}

Chronic viral hepatitis

HCV

Liver biopsy

Orthotopic-liver-transplantation (OLT)

Real time PCR

Direct acting antivirals (DAA)

\begin{abstract}
A B S T R A C T
Background \& aims: We evaluated the performance of a rapid method to quantify HCV-RNA in the hepatic and extrahepatic compartments, by using for the first time the Abbott RealTime HCV-assay.

Methods: Non-tumoral (NT), tumoral (TT) liver samples, lymph nodes and ascitic fluid from patients undergoing orthotopic-liver-transplantation $(\mathrm{N}=18)$ or liver resection $(\mathrm{N}=4)$ were used for the HCV-RNA quantification; $5 / 22$ patients were tested after or during direct acting antivirals (DAA) treatment. Total RNA and DNA quantification from tissue-biopsies allowed normalization of HCV-RNA concentrations in IU/ $\mu$ g of total RNA and IU $/ 10^{6}$ liver-cells, respectively.

Results: HCV-RNA was successfully quantified with high reliability in liver biopsies, lymph nodes and ascitic fluid samples. Among the 17 untreated patients, a positive and significant HCV-RNA correlation between serum and NT liver-samples was observed (Pearson: rho $=0.544, \mathrm{p}=0.024$ ). Three DAA-treated patients were HCVRNA "undetectable" in serum, but still "detectable" in all tested liver-tissues. Differently, only one DAA-treated patient, tested after sustained-virological-response, showed HCV-RNA "undetectability" in liver-tissue.

Conclusions: HCV-RNA was successfully quantified with high reliability in liver bioptic samples and extrahepatic compartments, even when HCV-RNA was "undetectable" in serum. Abbott RealTime HCV-assay is a good diagnostic tool for HCV quantification in intra- and extra-hepatic compartments, whenever a bioptic sample is available
\end{abstract}

\section{Introduction}

Advanced liver disease caused by hepatitis C virus (HCV) infection is the leading indication for orthotopic liver transplantation (OLT) worldwide (Saab et al., 2003).

The post-OLT detection of HCV-RNA in the serum or graft is extremely common, occurring in more than $95 \%$ of cases (Berenguer, 2002). During post-OLT follow up, elevated liver enzymes warrant liver biopsies for accurate diagnosis and treatment and it can be difficult to differentiate between acute rejection and recurrence of hepatitis C (Song et al., 2015). HCV treatment before OLT may reduce or eliminate the risk of post-OLT recurrence. In a pilot study, Sofosbuvir and ribavirin treatment before OLT successfully prevented HCV recurrence in $70 \%$ of patients with chronic HCV infection and liver cancer who achieved an HCV-RNA level less than $25 \mathrm{IU} / \mathrm{ml}$ before transplantation
(Curry et al., 2015). The recurrence of HCV infection after OLT in the remaining $30 \%$ of patients may be the consequence of a low-level residual viremia, not detectable by current commercial assays in serum. The liver is the primary site of HCV replication, and a direct correlation between liver and serum viral loads has been already established (McGuinness et al., 1996; De Moliner et al., 1998). The quantification of HCV-RNA in both serum and liver might provide helpful and more accurate information regarding the HCV burden and eventual risk of recurrence of HCV infection.

Several home-made methods, based on reverse transcription-polymerase chain reaction (RT-PCR), transcription-mediated amplification, or branched-chain DNA, are available for the detection of HCV-RNA in both serum and liver (Sakamoto et al., 1994; Dailey et al., 1999; Maudar et al., 2012; Ramirez et al., 2009; Harouaka et al., 2016; Hedegaard et al., 2017; Gambato et al., 2016). However, a commercial

\footnotetext{
Abbreviations: OLT, orthotopic-liver-transplantation; DAA, direct acting antivirals; NT, non-tumoral tissue; TT, tumoral tissue; HCC, hepatocellular carcinoma

* Corresponding author at: Department of Experimental Medicine and Surgery, University of Rome Tor Vergata, Via Montpellier 1, Rome 00133, Italy.

E-mail address: ceccherini@med.uniroma2.it (F. Ceccherini-Silberstein).
} 
Table 1

Patients Characteristics. PT: Patient; M: Male; F: Female; HCC: Hepatocellular Carcinoma; OLT: Orthotopic Liver Transplantation; LR: Liver Resection; HCV: Hepatitis C Virus; IU/ $\mathrm{ml}$ : International Unit per milliliter; TND: target not detected (HCV-RNA $<12 \mathrm{IU} / \mathrm{ml}$ ). Four patients were receiving a treatment with direct acting antivirals agents (DAA) before OLT

\begin{tabular}{|c|c|c|c|c|c|c|}
\hline ID & Age (Years) & Gender & Liver disease & $\begin{array}{c}\text { Surgical } \\
\text { Operation }\end{array}$ & $\begin{array}{c}\text { HCV } \\
\text { Genotype }\end{array}$ & $\begin{array}{l}\text { Serum } \\
\text { HCV- } \\
\text { RNA } \\
(\mathrm{IU} / \mathrm{ml})\end{array}$ \\
\hline PT1 & 58 & M & HCC & OLT & $3 a$ & 6643 \\
\hline PT2 & 71 & M & HCC & LR & $1 \mathrm{~b}$ & 695503 \\
\hline PT5 & 64 & M & HCC & OLT & $1 \mathrm{~b}$ & 1000 \\
\hline PT6 & 57 & M & HCC & OLT & $3 a$ & 490 \\
\hline PT22 & 74 & M & HCC & LR & $1 \mathrm{~b}$ & 54503 \\
\hline PT77 & 53 & $\mathrm{~F}$ & HCC & OLT & $1 \mathrm{~b}$ & 24 \\
\hline PT15 & 59 & M & Cirrhosis, HCC & OLT & $1 \mathrm{a}$ & 64092 \\
\hline PT19 & 48 & M & Cirrhosis, HCC & OLT & $1 \mathrm{a}$ & 2317 \\
\hline PT27 & 63 & M & Cirrhosis, HCC & OLT & $1 \mathrm{~b}$ & TND \\
\hline PT28 & 53 & M & Cirrhosis, HCC & OLT & $3 a$ & 6747 \\
\hline РT37 & 64 & $\mathrm{~F}$ & Cirrhosis, HCC & OLT & $1 \mathrm{~b}$ & TND \\
\hline PT40 & 61 & M & Cirrhosis, HCC & OLT & $3 a$ & 2089296 \\
\hline PT43 & 62 & M & Cirrhosis, HCC & OLT & $1 \mathrm{~b}$ & 1376956 \\
\hline PT44 & 71 & M & Cirrhosis, HCC & LR & $1 \mathrm{~b}$ & 710075 \\
\hline PT49 & 60 & M & Cirrhosis, HCC & OLT & $1 \mathrm{~b}$ & 75157 \\
\hline PT57 & 66 & M & Cirrhosis, HCC & OLT & $1 \mathrm{~b}$ & 57216 \\
\hline PT62 & 63 & $\mathrm{~F}$ & Cirrhosis, HCC & OLT & 2 & TND \\
\hline PT63 & 55 & M & Cirrhosis, HCC & OLT & $3 a$ & TND \\
\hline PT64 & 55 & M & Cirrhosis, HCC & LR & $4 d$ & 1000451 \\
\hline PT18 & 59 & M & Cirrhosis & OLT & $1 \mathrm{~b}$ & 171419 \\
\hline PT20 & 46 & M & Cirrhosis & OLT & $1 \mathrm{a}$ & 166694 \\
\hline PT53 & 46 & M & Cirrhosis & OLT & $1 \mathrm{a}$ & 387 \\
\hline
\end{tabular}

validated assay for the HCV RNA quantification in the liver tissue is still missing.

For the first time, we evaluated the performance of a rapid method to quantify the HCV-RNA in liver tissue, lymph nodes and ascitic fluids by using the Abbott RealTime HCV assay.

\section{Materials and methods}

\subsection{Study population}

We collected liver biopsies, on both non-tumoral (NT) and tumoral (TT) tissues, from 22 patients (19 men and 3 women, mean age 59 years, range: 46-74) with HCV infection by genotype $1 \mathrm{a}(\mathrm{n}=4), 1 \mathrm{~b}$ $(\mathrm{n}=11), 2(\mathrm{n}=1), 3 \mathrm{a}(\mathrm{n}=5)$ and $4 \mathrm{~d}(\mathrm{n}=1)$. Lymph nodes and ascitic fluids were also collected from 3 and 2 patients, respectively.

Most of the patients underwent liver surgery due to the presence of Hepatocellular Carcinoma (HCC) ( $=19)$ (Table 1). 18/22 underwent OLT and 4/22 liver resection. Five out of 22 patients (22.7\%) were receiving a treatment with direct acting antivirals (DAA) before OLT. All samples were obtained after written consent, which was approved by the local ethics commission.

\subsection{HCV-RNA quantification in liver biopsies by Abbott RealTime HCV assay}

The Abbott RealTime HCV assay was used for the quantification of HCV-RNA in liver, lymph nodes, ascitic fluids and sera samples (Abbott Laboratories, Abbott Park, Illinois, U.S.A.). For the HCV-RNA quantification in the liver, the protocol was applied in more than one patient's liver section to test the reliability of the HCV-RNA values.

Liver biopsies were obtained during OLT or liver resection. At the time of biopsy, tissue samples were promptly submerged in $1 \mathrm{ml}$ of RNAlater RNA Stabilization Reagent (Qiagen, Valencia, CA) and maintained over night at $4{ }^{\circ} \mathrm{C}$, and then stored at $-20^{\circ} \mathrm{C}$. Where it was available, lymph nodes biopsies and ascitic fluids were collected as well: the lymph nodes were stored in the same way as the liver biopsies;
Table 2

RNA and DNA measurements. PT: Patient; NT: Non Tumoral; TT: Tumoral Tissue; LN: Lymph node; n.a.: Sample Not Available; ng/ $\mu$ l: nanogram per microliter.

\begin{tabular}{|c|c|c|c|c|c|c|c|}
\hline ID & $\begin{array}{l}\text { Bioptic } \\
\text { Sample }\end{array}$ & $\begin{array}{c}\text { Total } \\
\text { RNA } \\
(\mathrm{ng} / \mu \mathrm{l})\end{array}$ & $260 / 280$ & $260 / 230$ & $\begin{array}{c}\text { Total } \\
\text { DNA } \\
(\mathrm{ng} / \mu \mathrm{l})\end{array}$ & $260 / 280$ & $260 / 230$ \\
\hline \multirow[t]{2}{*}{ PT1 } & NT & 96.7 & 2.14 & 1.91 & n.a. & n.a. & n.a. \\
\hline & TT & 28.4 & 1.85 & 1.61 & n.a. & n.a. & n.a. \\
\hline \multirow[t]{2}{*}{ PT2 } & NT & 24.3 & 1.96 & 1.94 & 129.8 & 1.88 & 1.99 \\
\hline & TT & 112.2 & 2.34 & 1.96 & 84.3 & 1.87 & 1.66 \\
\hline \multirow[t]{2}{*}{ PT5 } & NT & 81.5 & 2.02 & 1.85 & n.a. & n.a. & n.a. \\
\hline & $\mathrm{TT}$ & 400.9 & 2.09 & 1.90 & n.a. & n.a. & n.a. \\
\hline \multirow[t]{2}{*}{ PT6 } & NT & 252.3 & 2.34 & 1.83 & n.a. & n.a. & n.a. \\
\hline & $\mathrm{TT}$ & 23.1 & 1.91 & 1.45 & n.a. & n.a. & n.a. \\
\hline \multirow[t]{2}{*}{ PT22 } & NT & 182.9 & 2.04 & 1.99 & 128.7 & 1.86 & 1.60 \\
\hline & TT & 53.7 & 2.05 & 1.91 & 81.6 & 1.90 & 1.98 \\
\hline \multirow[t]{2}{*}{ PT77 } & NT & 470 & 1.98 & 1.84 & n.a. & n.a. & n.a. \\
\hline & TT & 397.9 & 2.08 & 1.93 & n.a. & n.a. & n.a. \\
\hline \multirow[t]{2}{*}{ PT15 } & NT & 277.6 & 2.07 & 1.98 & 176.7 & 1.90 & 2.09 \\
\hline & $\mathrm{TT}$ & 326.4 & 2.06 & 1.83 & 178.9 & 1.90 & 2.15 \\
\hline \multirow[t]{2}{*}{ PT19 } & NT & 46.4 & 2.04 & 1.77 & 139.2 & 1.87 & 1.74 \\
\hline & $\mathrm{TT}$ & 88.9 & 2.05 & 2.07 & 127.3 & 1.90 & 1.94 \\
\hline \multirow[t]{3}{*}{ PT27 } & NT & 30.2 & 2.07 & 1.96 & 125.6 & 1.86 & 1.21 \\
\hline & $\mathrm{TT}$ & 169.3 & 2.07 & 2.02 & 98.8 & 1.90 & 2.01 \\
\hline & $\mathrm{LN}$ & 4.7 & 2.13 & 1.86 & n.a. & n.a. & n.a. \\
\hline \multirow[t]{2}{*}{ PT28 } & NT & 26.8 & 2.08 & 1.74 & 41.5 & 1.93 & 1.18 \\
\hline & $\mathrm{TT}$ & 86.4 & 2.40 & 1.32 & 228.7 & 1.88 & 1.90 \\
\hline \multirow[t]{3}{*}{ PT37 } & NT & 314 & 2.13 & 2.07 & n.a. & n.a. & n.a. \\
\hline & $\mathrm{TT}$ & n.a. & n.a. & n.a. & n.a. & n.a. & n.a. \\
\hline & $\mathrm{LN}$ & 3.6 & 2.31 & 1.92 & n.a. & n.a. & n.a. \\
\hline \multirow[t]{2}{*}{ PT40 } & NT & 446.3 & 2.06 & 1.90 & 114.9 & 1.89 & 1.74 \\
\hline & $\mathrm{TT}$ & 1.3 & 2.54 & 2.02 & 7,0 & 2.38 & 0.21 \\
\hline \multirow[t]{3}{*}{ PT43 } & NT & 266.2 & 2.13 & 1.96 & n.a. & n.a. & n.a. \\
\hline & $\mathrm{TT}$ & 248.6 & 2.05 & 1.79 & n.a. & n.a. & n.a. \\
\hline & $\mathrm{LN}$ & 239.1 & 1.97 & 1.89 & n.a. & n.a. & n.a. \\
\hline \multirow[t]{2}{*}{ PT44 } & NT & 364.3 & 1.87 & 1.65 & n.a. & n.a. & n.a. \\
\hline & $\mathrm{TT}$ & 214 & 1.93 & 1.83 & n.a. & n.a. & n.a. \\
\hline \multirow[t]{2}{*}{ PT49 } & NT & 718.7 & 2.05 & 2.00 & 142.5 & 1.86 & 2.08 \\
\hline & $\mathrm{TT}$ & 7.2 & 1.92 & 1.75 & 71.1 & 1.94 & 1.76 \\
\hline \multirow[t]{2}{*}{ PT57 } & NT & 463.3 & 2.09 & 1.98 & n.a. & n.a. & n.a. \\
\hline & $\mathrm{TT}$ & 301.6 & 2.14 & 1.77 & n.a. & n.a. & n.a. \\
\hline \multirow[t]{2}{*}{ PT62 } & NT & 135 & 2.23 & 1.88 & n.a. & n.a. & n.a. \\
\hline & $\mathrm{TT}$ & 170 & 1.99 & 1.81 & n.a. & n.a. & n.a. \\
\hline \multirow[t]{2}{*}{ PT63 } & NT & 229.9 & 2.10 & 1.99 & n.a. & n.a. & n.a. \\
\hline & $\mathrm{TT}$ & 328.3 & 1.93 & 1.91 & n.a. & n.a. & n.a. \\
\hline \multirow[t]{2}{*}{ PT64 } & NT & 1115.1 & 2.41 & 1.99 & n.a. & n.a. & n.a. \\
\hline & $\mathrm{TT}$ & 96.8 & 1.86 & 1.65 & n.a. & n.a. & n.a. \\
\hline \multirow[t]{2}{*}{ PT18 } & NT & 142.9 & 2.04 & 1.86 & n.a. & n.a. & n.a. \\
\hline & $\mathrm{TT}$ & n.a. & n.a. & n.a. & n.a. & n.a. & n.a. \\
\hline \multirow[t]{2}{*}{ PT20 } & NT & 215 & 1.86 & 1.76 & n.a. & n.a. & n.a. \\
\hline & $\mathrm{TT}$ & n.a. & n.a. & n.a. & n.a. & n.a. & n.a. \\
\hline PT53 & NT & 114.6 & 2.35 & 1.94 & n.a. & n.a. & n.a. \\
\hline & $\mathrm{TT}$ & n.a. & n.a. & n.a. & n.a. & n.a. & n.a. \\
\hline
\end{tabular}

instead, the ascitic fluids were stored directly at $-20{ }^{\circ} \mathrm{C}$ like a normal serum sample.

According to samples availability, HCV-RNA quantification was performed by using $13 \mathrm{mg}$ of tissue section ( $5 \mathrm{~mm}$ of thickness in both liver and lymph node bioptic samples). A total of 56 NT liver sections obtained from 22 patients were used for HCV-RNA quantification. The number of NT liver sections obtained from each patient varied as follows: 3-4 different NT liver sections obtained from 14 patients, 2 different NT liver sections obtained from 5 patients, 1 NT liver section obtained from 3 patients. In addition, a total of 44 TT liver sections from 18/19 patients with HCC were assessed for HCV-RNA concentration. The breakdown of available TT liver sections per patient was as follows: 3 different TT liver sections obtained from 11 patients, 2 different TT liver sections obtained from 4 patients, 1 TT liver section obtained from 3 patients. No replicates were applied for the HCV-RNA quantification in lymph nodes and ascitic fluids because of the reduced availability of these samples.

The liver, or lymph node, bioptic sample was homogenized in $600 \mu \mathrm{l}$ of Buffer RLT (supplied by RNeasy Mini Kit, Qiagen, Valencia, CA) + $\beta$ - 


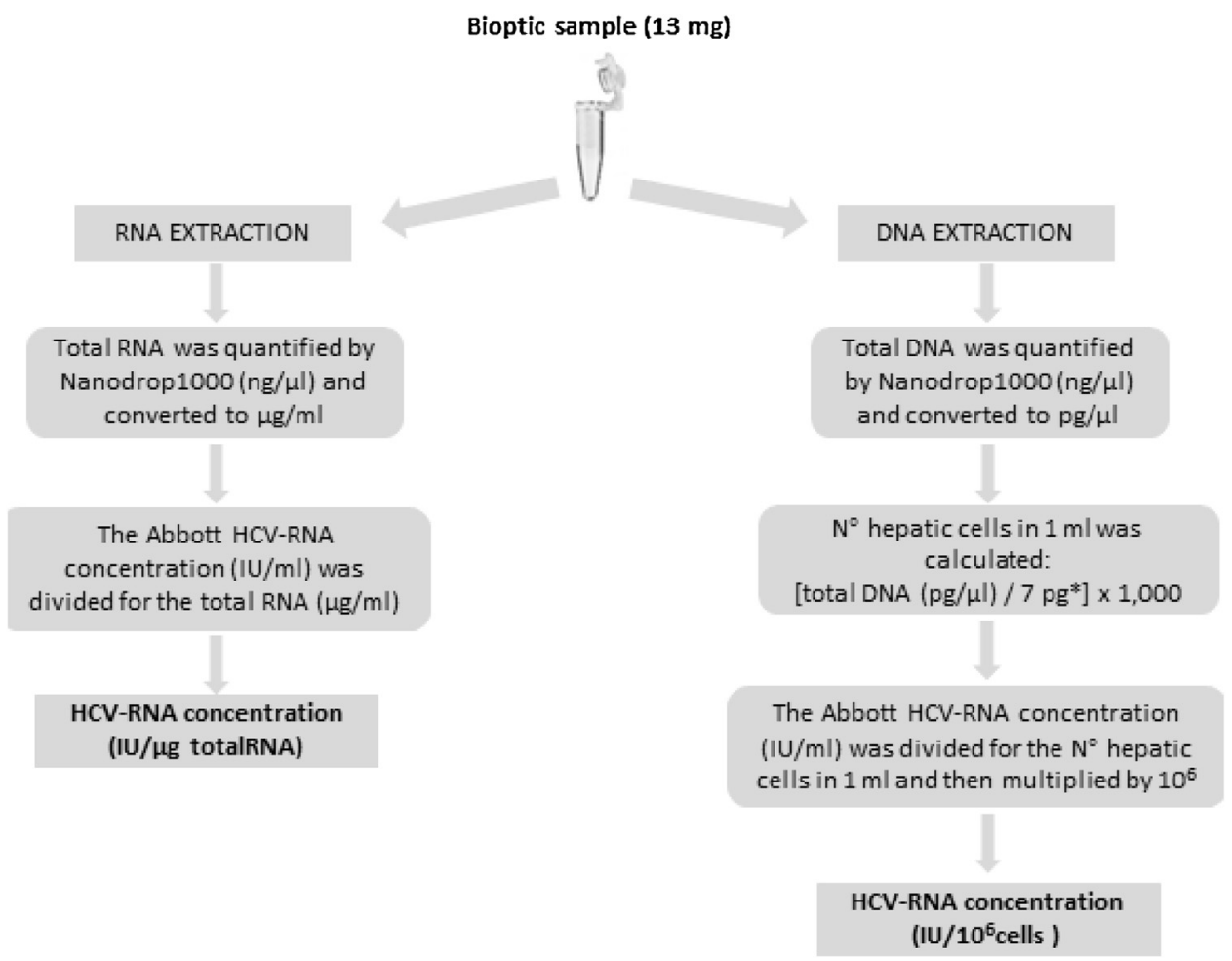

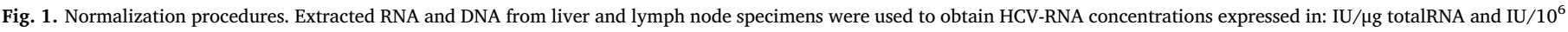
cells. *Total DNA amount per cell: 7 pg (Serth et al., 2000).

Mercaptoethanol by TissueRuptor (Qiagen, Valencia, CA) homogenizer; the homogenized sample was centrifuged for $3 \mathrm{~min}$ at full speed. Carefully, $333 \mu$ supernatant was removed and transferred into a new microcentrifuge tube containing $667 \mu \mathrm{l}$ of RNase-free water. This dilution (1:3) was made considering the requirement of $1 \mathrm{ml}$ of sample volume for the Abbott RealTime HCV assay, although the extraction volume used is $0.5 \mathrm{ml}$. HCV-RNA was then extracted automatically by the Abbott m2000sp system. Amplification and detection was performed, always automatically, by the Abbott m2000rt, which amplify the $5^{\prime}$ UTR region of the HCV genome. At each cycle, the amplified products were detected by the Abbott m2000rt through the HCV probe fluorescent signal, which is proportional to the log of HCV-RNA concentration present in the original sample.

The concentrations of HCV-RNA samples and controls were calculated from the stored calibration curved; the results were automatically reported on the Abbott m2000rt workstation and multiplied by the dilution factors to obtain the normalized Abbott HCV-RNA result (IU/ ml). The Abbott RealTime HCV Negative Control (-), Low Positive Control $(+)$, and High Positive Control $(++)$ were included in each run to verify run validity.

Afterwards, depending on the samples availability, total RNA and DNA extractions from 2 liver bioptic samples, $1 \mathrm{NT}$ and 1 TT, for each patient were performed by using the AllPrep DNA/RNA/Protein Mini Kit (Qiagen, Valencia, CA); subsequently, the extracted samples were quantified by Nanodrop1000 (Thermo Fisher Scientific Co., Ltd, Shanghai, China) to have both qualitative and quantitative measurements (Table 2). These measurements were used to normalize the Abbott HCV-RNA values (IU/ml) to obtain concentrations expressed as:

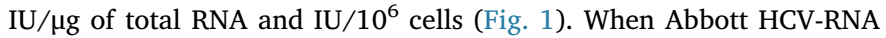
values were $<12 \mathrm{IU} / \mathrm{ml}$, the value of 12 was used for the normalization.

Since every liver sample was already used for the quantification of the HCV-RNA and for the extraction of the total RNA, the HCV-RNA IU/ $10^{6}$ cells normalization was performed in $8 / 22$ patients, where both NT and NT samples were still available to allow extra DNA quantification.

For the HCV RNA quantification in lymph nodes, values were normalized only by using the $\mu \mathrm{g}$ of total RNA. For the ascitic fluid, the same extraction protocol was used as above; in fact, the sample was directly diluted (1:3), and automatically extracted and quantified by the Abbott $m 2000 s p$ and Abbott m2000rt, respectively. The concentration was expressed in $\mathrm{IU} / \mathrm{ml}$.

\subsection{Statistical analysis}

All patients were coded for anonymity and for each patient, virological and clinical data were collected in an anonymous database. Results are expressed as median values and interquartile range (IQR). Values were compared using the Mann-Whitney $U$ test, the Pearson or the Spearman correlation test. All the analyses were performed using SPSS software package (version 19.0) for Windows (SPSS Inc., Chicago, Illinois).

\section{Results}

\subsection{HCV-RNA liver quantification and normalization}

Considering the Nanodrop1000 measurements, the extracted RNA and DNA from hepatic specimens were of good quality (average of the RNA and DNA absorbances at 260/280 nm: $2.09 \pm 0.16 \mathrm{SD}$ and $1.92 \pm 0.12 \mathrm{SD}$, respectively; average of the RNA and DNA absorbances at 260/230 nm: $1.86 \pm 0.15 \mathrm{SD}$ and $1.70 \pm 0.47 \mathrm{SD}$, respectively) (Table 2).

HCV-RNA was quantified successfully in all patients, by Abbott RealTime HCV assay, in both liver bioptic sections: NT (22 patients) and TT (18 patients with HCC).

The normalization procedures (IU/ $\mu$ g RNA and/or IU $/ 10^{6}$ cells) (Fig. 1) were applied to each liver sample; afterwards a mean HCV-RNA concentration was calculated per patient (Tables 3 and 4).

The obtained results, starting from both NT and TT samples, showed little variation in the triplicate quantifications performed in almost every patient, where it was available. In only one patient (PT28), the standard deviation among the 3 TT measurements was higher than the 
Table 3

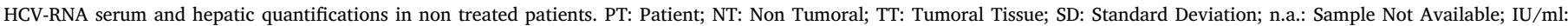

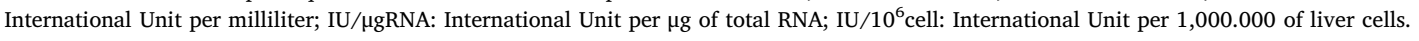

\begin{tabular}{|c|c|c|c|c|c|c|c|}
\hline ID & $\begin{array}{l}\text { Serum HCV- } \\
\text { RNA (IU/ml) }\end{array}$ & $\begin{array}{c}\text { Tissue NT HCV- } \\
\text { RNA (IU/ml) }\end{array}$ & $\begin{array}{l}\text { Tissue NT HCV- } \\
\text { RNA (IU/ } \mu g R N A) \\
\text { Mean } \pm \text { SD }\end{array}$ & $\begin{array}{c}\text { Tissue NT HCV-RNA } \\
\text { (IU } / 10^{6} \text { cells) } \\
\text { Mean } \pm \text { SD }\end{array}$ & $\begin{array}{l}\text { Tissue TT HCV- } \\
\text { RNA (IU/ml) }\end{array}$ & $\begin{array}{c}\text { Tissue TT HCV-RNA } \\
\text { (IU/ } \mu \text { gRNA) } \\
\text { Mean } \pm \mathrm{SD}\end{array}$ & $\begin{array}{c}\text { Tissue TT HCV-RNA } \\
\text { (IU } / 10^{6} \text { cells) } \\
\text { Mean } \pm \text { SD }\end{array}$ \\
\hline PT1 & 6643 & $\begin{array}{c}56000 \\
63392 \\
169470 \\
176656\end{array}$ & $1204 \pm 587$ & n.a. & 720 & 25.4 & n.a. \\
\hline PT2 & 695503 & $\begin{array}{l}1763640 \\
2265876 \\
2218698\end{array}$ & $85709 \pm 9319$ & $112320 \pm 12213$ & $\begin{array}{c}202941 \\
1664208 \\
2234313\end{array}$ & $12185 \pm 7625$ & $113524 \pm 71037$ \\
\hline PT5 & 1000 & $\begin{array}{l}452268 \\
274194 \\
534366\end{array}$ & $5157 \pm 1332$ & n.a. & $\begin{array}{c}729 \\
1386 \\
558\end{array}$ & $2 \pm 0.9$ & n.a. \\
\hline PT6 & 490 & 799686 & 3170 & n.a. & $\begin{array}{l}1973943 \\
1933209 \\
8858295\end{array}$ & $184206 \pm 140907$ & n.a. \\
\hline PT22 & 54503 & $\begin{array}{l}25285725 \\
23728878 \\
29955087\end{array}$ & $143889 \pm 14461$ & $1431722 \pm 143894$ & $\begin{array}{l}2212812 \\
5019435 \\
5740074\end{array}$ & $80523 \pm 28336$ & $370941 \pm 130531$ \\
\hline PT15 & 64092 & $\begin{array}{l}4062609 \\
8246214 \\
6118479\end{array}$ & $22127 \pm 6153$ & $243334 \pm 67664$ & $\begin{array}{l}2851542 \\
5325489 \\
4700061\end{array}$ & $13151 \pm 3218$ & $167952 \pm 41097$ \\
\hline PT19 & 2317 & $\begin{array}{c}1017 \\
1206 \\
567\end{array}$ & $20 \pm 5.8$ & $47 \pm 13$ & $\begin{array}{c}2097 \\
621 \\
1197\end{array}$ & $15 \pm 6.8$ & $72 \pm 33$ \\
\hline PT28 & 6747 & $\begin{array}{l}7195230 \\
7999110 \\
8228250\end{array}$ & $291326 \pm 16528$ & $1316933 \pm 74715$ & $\begin{array}{c}2925 \\
58302 \\
4041\end{array}$ & $252 \pm 299$ & $666 \pm 791$ \\
\hline PT40 & 2089296 & $\begin{array}{l}13128246 \\
16854588 \\
19230399\end{array}$ & $36756 \pm 5627$ & $999398 \pm 153004$ & $\begin{array}{l}18873 \\
29421 \\
25254\end{array}$ & $18858 \pm 3337$ & $24516 \pm 4338$ \\
\hline PT43 & 1376956 & $\begin{array}{l}13023081 \\
12752748 \\
11644677\end{array}$ & $46858 \pm 2240$ & n.a. & 1278 & 5.1 & n.a. \\
\hline PT44 & 710075 & $\begin{array}{l}3149397 \\
1893102\end{array}$ & $6921 \pm 1724$ & n.a. & 32490 & 152 & n.a. \\
\hline PT49 & 75157 & $\begin{array}{c}8947621156734 \\
663894\end{array}$ & $1259 \pm 280$ & $44463 \pm 9890$ & $\begin{array}{c}1332 \\
152433 \\
67671\end{array}$ & $10252 \pm 8589$ & $7267 \pm 6088$ \\
\hline PT57 & 57216 & $\begin{array}{l}1122396 \\
2248299\end{array}$ & $3638 \pm 1215$ & n.a. & $\begin{array}{c}437421 \\
1137492\end{array}$ & $2612 \pm 1161$ & n.a. \\
\hline PT64 & 1000451 & $\begin{array}{l}3022068 \\
2880009\end{array}$ & $2646 \pm 64$ & n.a. & $\begin{array}{l}21357 \\
75192\end{array}$ & $499 \pm 278$ & n.a. \\
\hline PT18 & 171419 & 553266 & 3872 & n.a. & n.a. & n.a. & n.a. \\
\hline PT20 & 166694 & 11297979 & 52549 & n.a. & n.a. & n.a. & n.a. \\
\hline PT53 & 387 & $\begin{array}{l}306 \\
387\end{array}$ & $3 \pm 0.4$ & n.a. & n.a. & n.a. & n.a. \\
\hline
\end{tabular}

mean value, but this unique variation might be correlated with different distribution of HCV-RNA in the 3 liver sections, or also by simply a methodological error.

When HCV-RNA concentration was expressed in IU/ $\mu \mathrm{g}$ of total RNA, quantification of HCV-RNA among NT samples varied from TND to

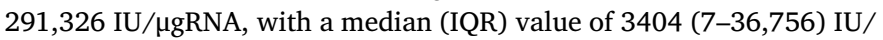

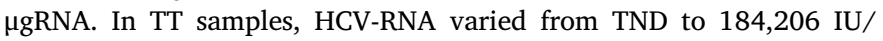

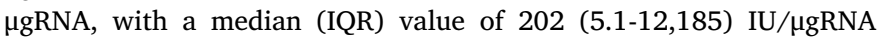
(Tables 3 and 4).

Similarly, when HCV-RNA was expressed in IU $/ 10^{6}$ cells, its concentration varied in NT samples from 11 to $1,431,722 \mathrm{IU} / 10^{6}$ cells, with a median (IQR) value of $177,827(22,255-1,158,166) \mathrm{IU} / 10^{6}$ cells. In TT samples, HCV-RNA varied from 72 to 370,941 IU/10 $0^{6}$ cells, with a median (IQR) value of 15,892 $(639-140,738)$ IU $/ 10^{6}$ cells (Tables 3 and 4).

\subsection{Comparison of HCV-RNA concentrations between serum and liver samples of non-treated patients}

Among the 17 untreated patients, a positive and significant HCV-
RNA correlation between serum and NT liver samples was observed (Pearson: rho $=0.544, \mathrm{p}=0.024$ ) only after the normalization with

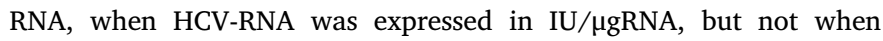
expressed in IU $/ 10^{6}$ cells (Panels A and B, Fig. 2). Differently, no correlation was observed between serum and TT (14/17 untreated patients) with both normalization methods (Panels C and D, Fig. 2).

In patients with HCC (14/17), the median (IQR) HCV-RNA concentration was generally higher in NT samples compared to TT samples, although this difference was not statistically significant. In fact, when tissue HCV-RNA was expressed in logIU/ $\mu$ gRNA, the median (IQR)

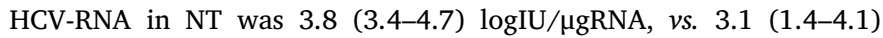
$\operatorname{logIU} / \mu g R N A$ in TT (Mann-Whitney, $\mathrm{p}=0.114$ ). Similarly, when tissue HCV-RNA was expressed in $\log \mathrm{IU} / 10^{6}$ cells, the median (IQR) HCVRNA in NT samples was 5.4 (4.6-6.1) $\log \mathrm{IU} / 10^{6}$ cells, vs. $4.4(2.8-5.2)$ $\log \mathrm{IU} / 10^{6}$ cells in TT samples (Mann-Whitney, $\mathrm{p}=0.209$ ).

By plotting TT and NT HCV-RNA results obtained with the 2 different normalization methods, the correlation between the 2 variables was positive by Pearson correlation test, yet not statistically significant (Panels E and F, Fig. 2). Notably, the normalization of HCVRNA values in $\mathrm{IU} / 10^{6}$ cells, where it was available, led to a more 
Table 4

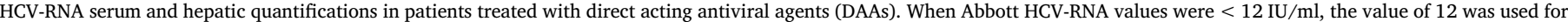

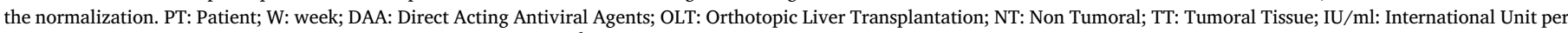

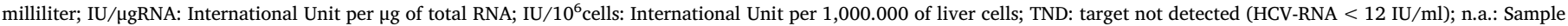
Not Available; SD: Standard Deviation; SVR, sustained virological response.

\begin{tabular}{|c|c|c|c|c|c|c|c|c|}
\hline ID & $\begin{array}{l}\text { Duration of DAA } \\
\text { treatment pre-OLT }\end{array}$ & $\begin{array}{l}\text { Serum HCV-RNA } \\
(\mathrm{IU} / \mathrm{ml})\end{array}$ & $\begin{array}{l}\text { Tissue NT HCV- } \\
\text { RNA (IU/ml) }\end{array}$ & $\begin{array}{c}\text { Tissue NT HCV- } \\
\text { RNA (IU/ } \mu \text { gRNA) } \\
\text { Mean } \pm \text { SD }\end{array}$ & $\begin{array}{c}\text { Tissue NT HCV- } \\
\text { RNA (IU } / 10^{6} \text { cells) } \\
\text { Mean } \pm \text { SD }\end{array}$ & $\begin{array}{l}\text { Tissue TT HCV- } \\
\text { RNA (IU/ml) }\end{array}$ & $\begin{array}{c}\text { Tissue TT HCV- } \\
\text { RNA (IU/ } \mu g R N A) \\
\text { Mean } \pm \text { SD }\end{array}$ & $\begin{array}{c}\text { Tissue TT HCV-RNA } \\
\text { (IU } / 10^{6} \text { cells) } \\
\text { Mean } \pm \text { SD }\end{array}$ \\
\hline PT27 & $6 \mathrm{w}$ & TND & $\begin{array}{l}297 \\
153 \\
153\end{array}$ & $7 \pm 2.2$ & $11 \pm 4$ & $\begin{array}{l}7902 \\
8910 \\
9108\end{array}$ & $51 \pm 3.1$ & $612 \pm 37$ \\
\hline PT37 & $19 w$ & TND & $\begin{array}{l}<12 \\
<12 \\
<12\end{array}$ & $0.1 \pm 0$ & n.a. & n.a. & n.a. & n.a. \\
\hline PT62 & $5 \mathrm{w}$ & TND & $\begin{array}{l}117 \\
<12 \\
<12\end{array}$ & $0.5 \pm 0.3$ & n.a. & $\begin{array}{l}<12 \\
<12 \\
<12\end{array}$ & $0.2 \pm 0$ & n.a. \\
\hline PT63 & SVR12 & TND & $\begin{array}{l}\text { TND } \\
\text { TND } \\
\text { TND }\end{array}$ & TND & n.a. & $\begin{array}{l}\text { TND } \\
\text { TND }\end{array}$ & TND & n.a. \\
\hline PT77 & $\begin{array}{l}\text { RELAPSER: } 12 \mathrm{w} \\
\text { before OLT }\end{array}$ & 24 & $\begin{array}{c}1977 \\
972\end{array}$ & $3.1 \pm 1.1$ & n.a. & $\begin{array}{l}<12 \\
<12\end{array}$ & $0.1 \pm 0$ & n.a. \\
\hline
\end{tabular}

marked linear correlation between TT and NT quantifications (rho $=0.666$, p-value $=0.103$ with HCV-RNA expressed in $\mathrm{IU} / 10^{6}$ cells, $v$ s. rho $=0.316$, p-value $=0.271$ with HCV-RNA expressed in IU/ $\mu \mathrm{gRNA})$.

\subsection{Comparison of HCV-RNA concentrations between serum and liver samples of treated patients}

Five patients started a DAA treatment before OLT. At the time of OLT, 3 patients were still in treatment, while 2 patients had completed therapy. One of these 2 patients, PT63, showed undetectable HCV-RNA at week-12 of follow-up (sustained virological response, SVR) (Table 4) while another was a relapser with low HCV RNA (PT77); indeed, the only patient who had undetectable HCV-RNA in both serum and all liver specimens was PT63.

Notably, at the moment of OLT, all the other 3 patients still in treatment had undetectable HCV-RNA in the serum, but had detectable HCV-RNA in liver tissues, confirmed also by the triplicate quantifications (Table 4). In fact, any liver tissue sample of these cases had HCVRNA "undetectable". Interestingly, one patient, who started sofosbuvir + ribavirin 6 weeks before OLT (PT27), showed still a consistent amount of HCV-RNA in both liver tissues, higher in TT than NT tissue

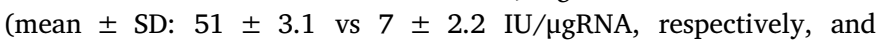
$612 \pm 37$ vs $11 \pm 4 \mathrm{IU} / 10^{6}$ liver cells, respectively).

\subsection{HCV-RNA quantification in extrahepatic tissue}

HCV-RNA was quantified successfully also in the few extrahepatic samples ( 2 ascitic fluids and 3 lymph nodes) by the Abbott RealTime HCV assay (Table 5). When patients were HCV-viremic, ascitic fluid and/or lymph nodes provided positive and quantified HCV-RNA values, differently, when patients had in the serum HCV-RNA as TND, also ascitic fluid and/or lymph nodes showed TND results.

\section{Discussion}

In this study, we have adapted a validated and highly sensitive technique, the Abbott RealTime HCV assay used for HCV-RNA measurement in serum, to quantify HCV-RNA in liver, lymph nodes and ascitic fluid samples collected from HCV patients undergoing OLT or liver resection.

The purpose of our study was to evaluate the reliability of a rapid and commercial method to quantify the HCV-RNA in intra- and extrahepatic compartments of untreated and DAA treated patients.

To our knowledge, the Abbott RealTime HCV assay was used for the first time to quantify HCV-RNA in liver, lymph nodes and ascitic fluids, starting directly from a homogenized tissue sample. In addition, after total RNA and DNA quantifications using the same amount of bioptic sample $(13 \mathrm{mg})$, two different normalization procedures were applied

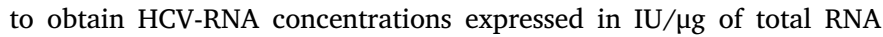
and/or IU $/ 10^{6}$ liver cells, respectively. This procedure has been used for the first time in our study (Ramirez et al., 2009; Harouaka et al., 2016; Hedegaard et al., 2017; Gambato et al., 2016), and even if the availability of liver samples didn't allow the IU $/ 10^{6}$ liver cells normalization for all patients, it seems a good alternative option. A possible limitation for this type of normalization is the absence of a significant correlation between HCV-RNA in serum and in NT or TT liver samples, probably related to the few cases normalized on cells number in this study.

The results of HCV-RNA quantification in both NT and TT samples showed overall a very small variation proved by the triplicate analysis, where it was available. The reliability of this test was particularly evident among the three measurements of the only treated patient who reached SVR before OLT (PT63), in which HCV-RNA was "undetectable" in all the NT and TT samples.

Notably, the result of "undetectable" HCV-RNA reported in the serum of the other 3 treated patients receiving DAA treatment was not confirmed in NT and TT samples, while it was confirmed in ascetic fluid and/or lymph nodes. This indicates that the Abbott RealTime HCV assay is highly sensitive in identifying potential residual HCV-RNA in the liver during treatment, even in the absence of circulating virus in the serum and in other compartments. This result may explain why some patients relapse after the end of treatment, due to the presence of residual HCV RNA in the liver, normally not analyzed.

Interestingly, all our patients, still on treatment during OLT, achieved SVR, independently from the duration of undetectable serum HCV-RNA before OLT, with the exception of PT37, who died immediately after OLT. Our results, though based on a very limited number of patients, are in line with recent data showing that patients with chronic HCV infection and liver cancer receiving sofosbuvir and ribavirin before OLT had no recurrence of HCV infection in $70 \%$ of cases when HCVRNA concentrations were less than $25 \mathrm{IU} / \mathrm{mL}$ before transplantation (Curry et al., 2015).

The positive correlation between serum viremia and HCV-RNA in NT tissue from untreated patients may indicate equilibrium between these two compartments: the viral particles released from infected 
A Pearson: $r h o=0.544, \mathbf{p}=\mathbf{0 . 0 2 4}$

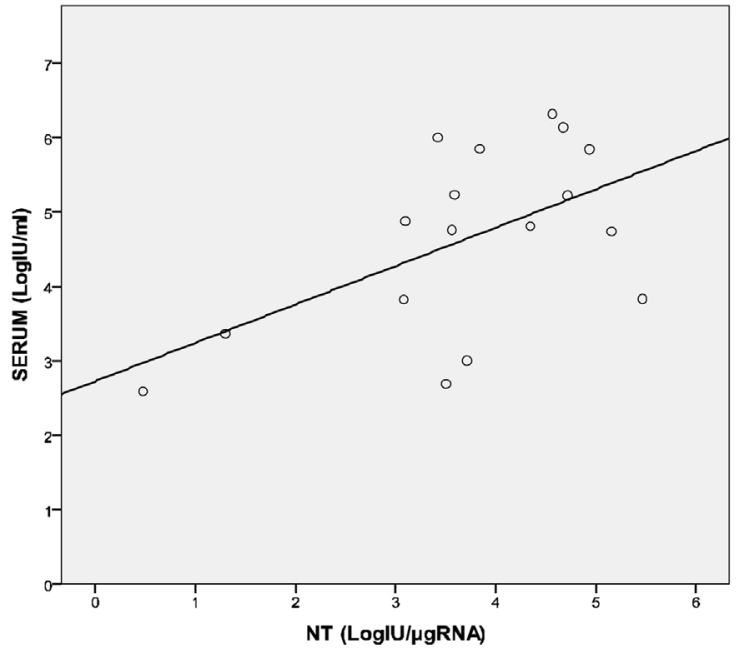

C Pearson: $r h o=0.135, p=0.646$

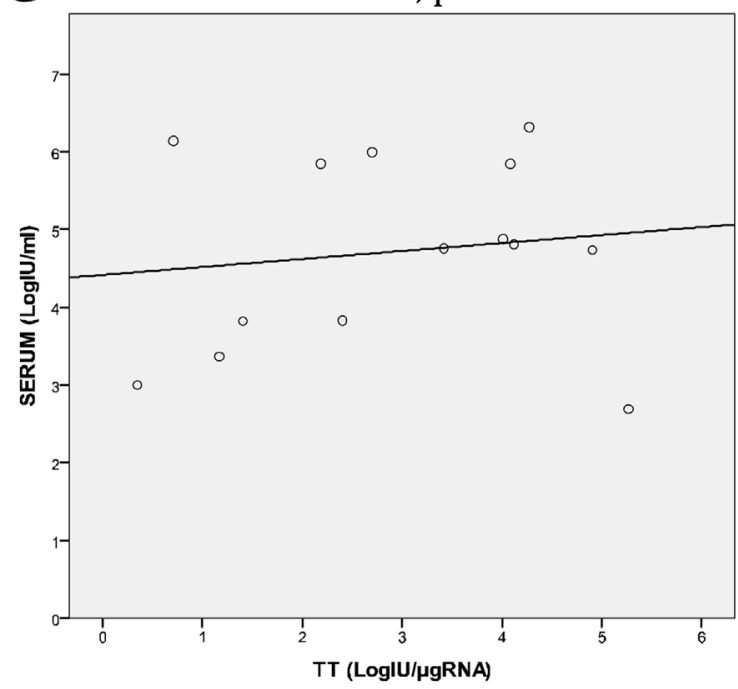

E Pearson: $r h o=0.316, p=0.271$

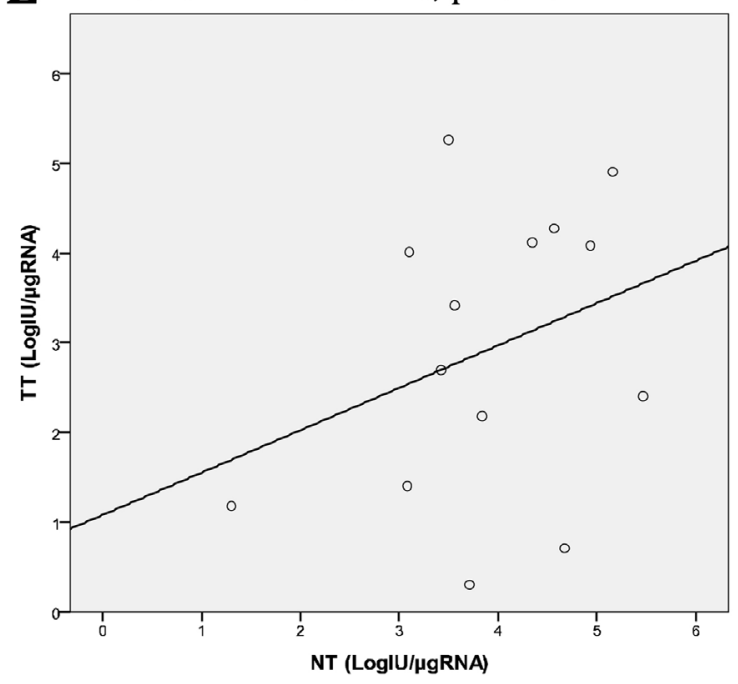

B Pearson: $r h o=0.528 p=0.223$

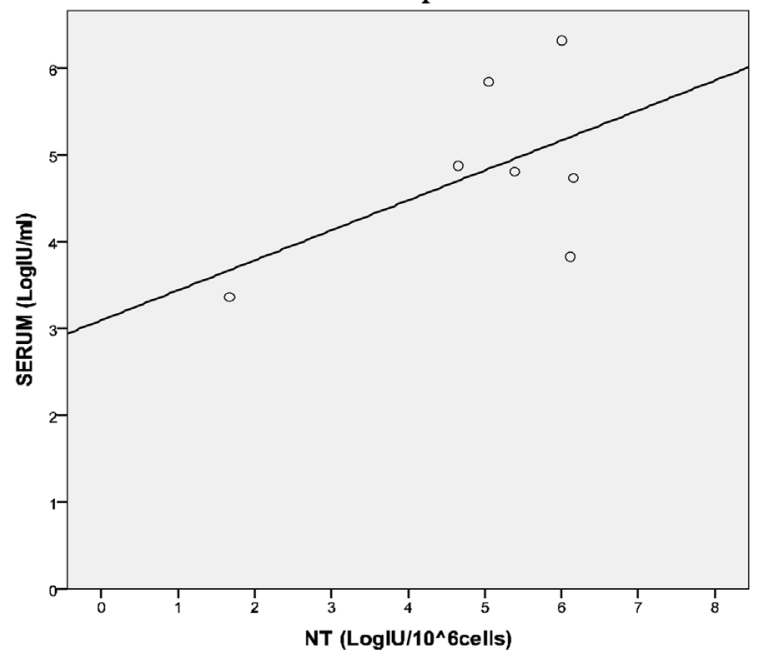

D Pearson: $r h o=0.685, \mathrm{p}=0.089$

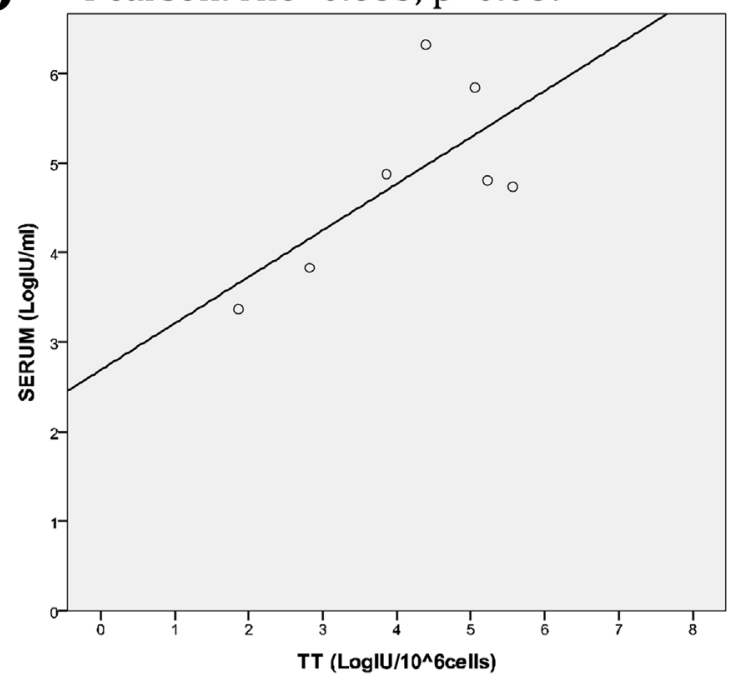

F Pearson: $r h o=0.666, p=0.103$

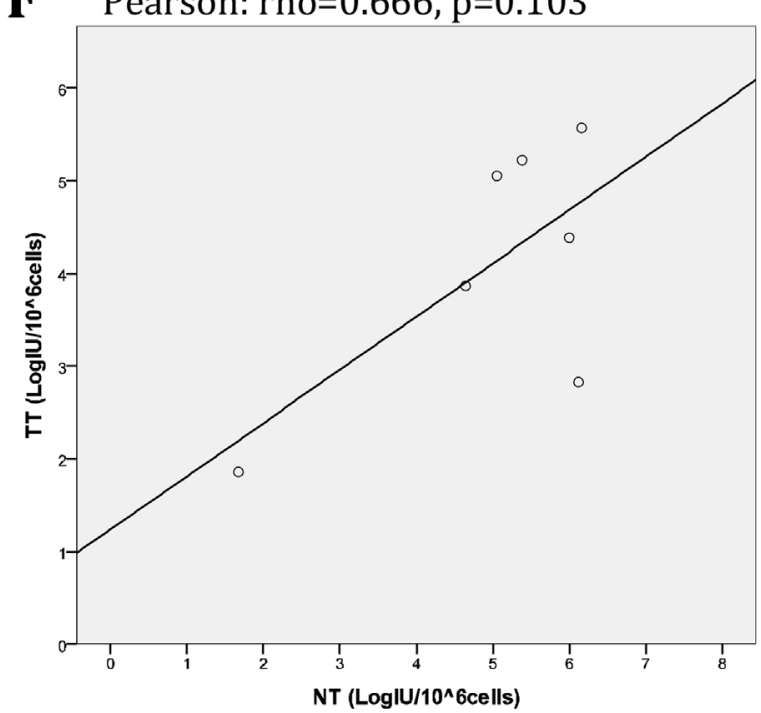

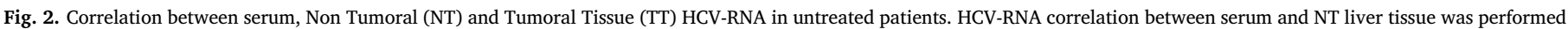

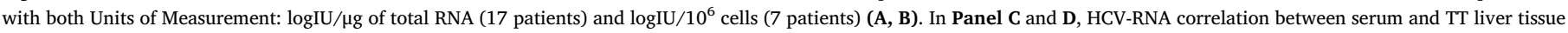

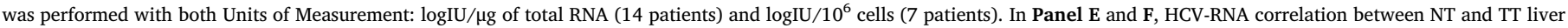
tissues was performed with both Units of Measurement: $\log I U / \mu g$ of total RNA (14 patients) and $\operatorname{logIU} / 10^{6}$ cells (7 patients). Significant P values are shown in bold. 
Table 5

HCV-RNA serum and extrahepatic quantifications in patients treated* and not treated with direct acting antiviral agents. PT: Patient; AF: Ascitic Fluid; LN: Lymph node; IU/ml:

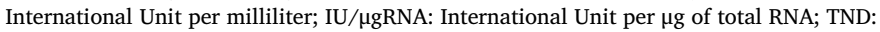
target not detected (HCV-RNA < $12 \mathrm{IU} / \mathrm{ml}$ ); n.a.: Sample Not Available.

\begin{tabular}{lcccc}
\hline ID & $\begin{array}{c}\text { Serum HCV-RNA } \\
(\mathrm{IU} / \mathrm{ml})\end{array}$ & $\begin{array}{c}\text { AF HCV-RNA } \\
(\mathrm{IU} / \mathrm{ml})\end{array}$ & $\begin{array}{c}\text { LN HCV-RNA } \\
(\mathrm{IU} / \mathrm{ml})\end{array}$ & $\begin{array}{c}\text { LN HCV-RNA (IU/ } \\
\mu g R N A)\end{array}$ \\
\hline PT27* & TND & TND & TND & TND \\
PT28 & 6747 & 711 & n.a. & n.a. \\
PT37* & TND & n.a. & TND & TND \\
PT43 & 1376956 & n.a. & 22875 & 95.7 \\
\hline
\end{tabular}

hepatocyte are "efficiently" vehiculated into portal circulation thanks to appropriate vascularization of non-tumoral tissue. On the contrary, HCC, which arises in the setting of cirrhosis, and fibrinogenesis, that results from liver injury and cirrhosis, lead to reduction in vascularization (Wu et al., 2007). The distorted vascularization of tumoral tissue, in association with the altered functionality of tumoral cells, may thus account for the weaker correlation among serum viremia and TT tissue HCV-RNA.

One limit of this study is that we analyzed bioptic liver samples obtained from surgical operations (mainly during OLT), with a general weight of $13 \mathrm{mg}$ of tissue. Future analysis will be required in order to validate the same quantification procedure in smaller bioptic samples obtained by needle aspiration. Furthermore, another limit is that the viral RNA for the quantification and total RNA/DNA were extracted by different procedures with unknown, but probably different, efficiency, as well as by using different liver samples. The quantification of total RNA/DNA from the same liver sample and by applying the same procedure would seem more appropriate, but in our case it was not possible due to the automatic Abbott system.

Interestingly, as a proof of concept for HCV-RNA quantification in extrahepatic compartments, the Abbott RealTime HCV assay was also used in a skin biopsy of a patient with cryoglobulinemia and itchy rashes, and the test confirmed the presence of HCV-RNA in the biopsy, with a concentration of $188.6 \mathrm{IU} / \mu \mathrm{gRNA}$.

In conclusion, our study shows that the Abbott RealTime HCV assay is a fast and reliable methodology for the quantification of HCV-RNA in tissues, whenever a liver (or extrahepatic) biopsy is available from a HCV infected patient.

\section{Contributors}

All the authors have accepted responsibility for the entire content of this submitted manuscript and approved submission.

\section{Competing interests}

None declared.

\section{Patient consent}

Obtained.

\section{Ethics approval}

The research study has been approved by the local ethics commit- tee, from the Polyclinic Tor Vergata Foundation.

\section{Acknowledgments}

We gratefully thank the Molecular Virology group of the Polyclinic Tor Vergata Foundation, particularly Dr. Sara Giannella for technical assistance, and the Abbott Molecular Italy for providing reagents and technical support, particularly Scientific Affairs Abbott Molecular team and Dr. Stefano Belladonna for his technical assistance. We thank Katherine Scott for the English manuscript revision.

This work was supported by the Italian Ministry of Instruction, University \& Research (MIUR) (Program agreements 2011: RBAP11YS7K_001, Bandiera InterOmics Protocol PB05 $1^{\circ}$ ) and by Aviralia Foundation. The funders had no role in study design, data collection and analysis, decision to publish, or preparation of the manuscript.

\section{References}

Berenguer, M., 2002. Natural history of recurrent hepatitis C. Liver Transpl. 8 (Suppl. 1 (10)), S14-S18.

Curry, M.P., Forns, X., Chung, R.T., et al., 2015. Sofosbuvir and ribavirin prevent recurrence of HCV infection after liver transplantation: an open-label study. Gastroenterology 148 (1), 100-107. http://dx.doi.org/10.1053/j.gastro.2014.09. 023. e1. Epub 2014 Sep 28.

Dailey, P.J., Collins, M.L., Urdea, M.S., et al., 1999. Quantification of HCV RNA in liver tissue by bDNA assay. Methods Mol. Med. 19, 119-129. http://dx.doi.org/10.1385/ 0-89603-521-2:119.

De Moliner, L., Pontisso, P., De Salvo, G.L., et al., 1998. Serum and liver HCV RNA levels in patients with chronic hepatitis C: correlation with clinical and histological features. Gut 42, 856-860.

Gambato, M., Pèrez-Del-Pulgar, S., Hedskog, C., et al., 2016. Hepatitis C virus RNA persists in liver explants of most patients awaiting liver transplantation treated with an interferon-Free regimen. Gastroenterology 151 (October (4)), 633-636. http://dx. doi.org/10.1053/j.gastro.2016.06.025. e3 Epub 2016 Jul 1.

Harouaka, D., Engle, R.E., Wollenberg, K., et al., 2016. Diminished viral replication and compartimentalization of hepatitis $\mathrm{C}$ virus in hepatocellular carcinoma tissue. PNAS 113 (February (5)), 1375-1380. http://dx.doi.org/10.1073/pnas.1516879113. Epub 2016 Jan 19.

Hedegaard, D.L., Tully, D.C., Rowe, I.A., et al., 2017. High resolution sequencing of hepatitis $C$ virus reveals limited intra-hepatic compartmentalization in end-stage liver disease. J. Hepatol. 66 (January (1)), 28-38. http://dx.doi.org/10.1016/j.jhep.2016. 07.048. Epub 2016 Aug 13

Maudar, K.K., Gandhi, P., Mishra, P.K., et al., 2012. Novel approach for quantification of hepatitis C virus in liver cirrhosis using real-time reverse transcriptase PCR. J. Gastrointest. Surg. 16 (January (1)), 142-146. http://dx.doi.org/10.1007/s11605 011-1750-0. discussion 146-7 Epub 2011 Nov 3.

McGuinness, P.H., Bishop, G.A., Painter, D.M., et al., 1996. Intrahepatic hepatitis C RNA levels do not correlate with degree of liver injury in patients with chronic hepatitis C. Hepatology 23, 676-687.

Ramirez, S., Perez del Pulgar, S., Carrion, J.A., et al., 2009. Hepatitis C virus compartmentalization and infection recurrence after liver transplantation. Am. J. Transplant. 9 (July (7)), 1591-1601. http://dx.doi.org/10.1111/j.1600-6143.2009. 02666.x. Epub 2009 May 20.

Saab, S., Wang, V., Ibrahim, A.B., et al., 2003. MELD score predicts 1-year patient survival post-orthotopic liver transplantation. Liver Transpl. 9 (5), 473-476.

Sakamoto, N., Enomoto, N., Kurosaki, M.L., et al., 1994. Detection and quantification of hepatitis C virus RNA replication in the liver. J. Hepatol. 20 (May (5)), 593-597.

Serth, J., Kuczyk, M.A., Paeslack, U., et al., 2000. Quantitation of DNA extracted after micropreparation of cells from frozen and formalin-fixed tissue sections. Am. J. Pathol. 156 (April (4)), 1189-1196.

Song, A.T., Mello, E.S., Alves, V.A., et al., 2015. Quantification of C4d deposition and hepatitis $C$ virus RNA in tissue in cases of graft rejection and hepatitis $C$ recurrence after liver transplantation. Memòrias Inst. Oswaldo Cruz. 110 (1), 56-64. http://dx. doi.org/10.1590/0074-02760140192. Epub 2015 Feb 13.

Wu, X.Z., Xie, G.R., Chen, D., 2007. Hypoxia and hepatocellular carcinoma: the therapeutic target for hepatocellular carcinoma. J. Gastroenterol. Hepatol. 22 (August (8)), 1178-1182 Epub 2007 Jun 7. 